\title{
HOXA9 wt Allele
}

National Cancer Institute

\section{Source}

National Cancer Institute. HOXA9 wt Allele. NCI Thesaurus. Code C52998.

Human HOXA9 wild-type allele is located within 7p15-p14 and is approximately $7 \mathrm{~kb}$ in length. This allele, which encodes homeobox protein Hox-A9, plays roles in both the modulation of transcription by RNA polymerase II and the development of the anterioposterior axis. 